\section{TRENDS IN WORLD MILITARY EXPENDITURE, 2018}

\author{
NAN TIAN, AUDE FLEURANT, ALEXANDRA KUIMOVA,
} PIETER D. WEZEMAN AND SIEMON T. WEZEMAN

World military expenditure is estimated to have been $\$ 1822$ billion in 2018 . It was 2.6 per cent higher in real terms than in 2017 and 5.4 per cent higher than in 2009. Global military spending has been gradually rising following a post-2009 low in 2014. It is now 76 per cent higher than the post-cold war low in 1998 (see figure 1).

This Fact Sheet presents regional and selected national military expenditure data for 2018 and trends over the decade 2009-18. The data is from the updated SIPRI Military Expenditure Database, which provides military expenditure data by country for the years 1949-2018.

The world military burden-global military expenditure as a share of global gross domestic product (GDP)-fell to 2.1 per cent in 2018. This equals the level of 2014-the lowest of the post-cold war period. Military spending per capita increased from $\$ 230$ in 2017 to $\$ 239$ in 2018, as the 1.1 per cent growth in world population was surpassed by the growth in military spending.

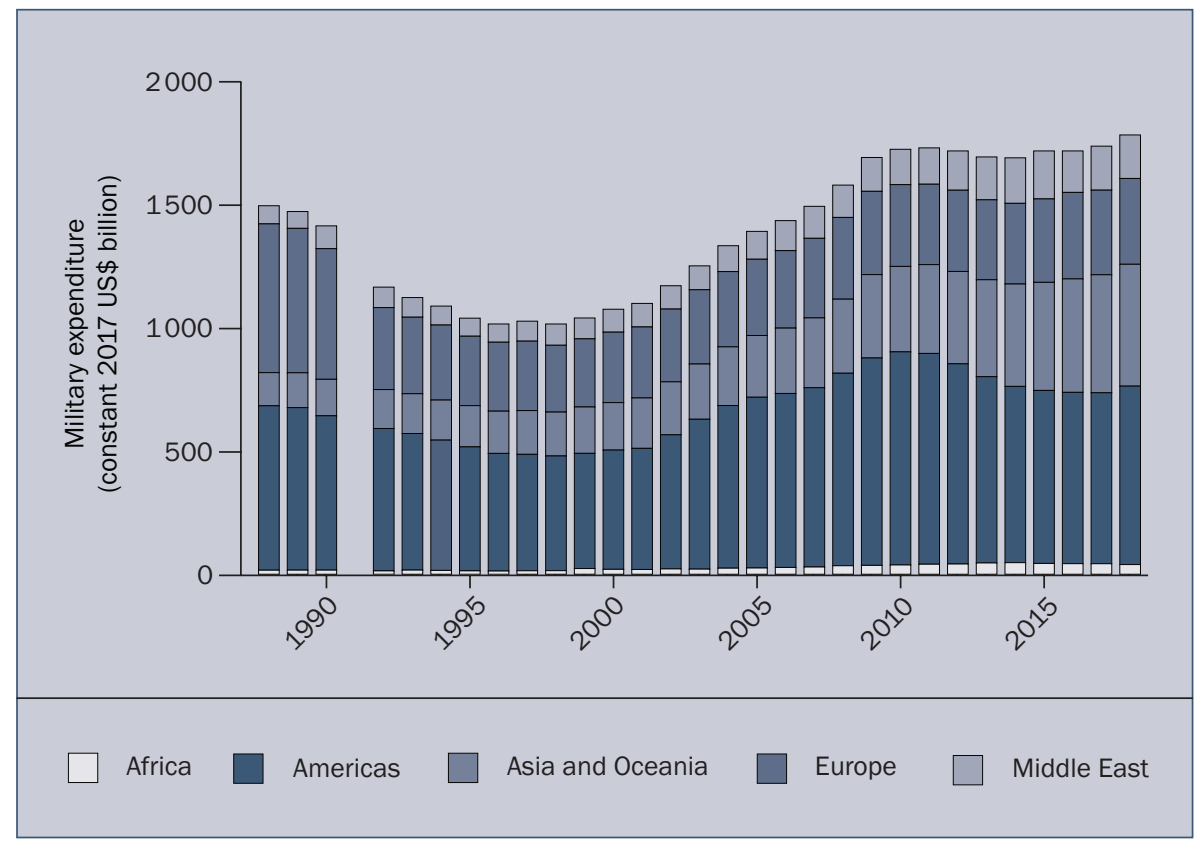

Figure 1. World military expenditure, by region, 1988-2018

Note: The absence of data for the Soviet Union in 1991 means that no total can be calculated for that year.

Source: SIPRI Military Expenditure Database, Apr. 2019.

\section{KEY FACTS}

- Global military expenditure was $\$ 1822$ billion in 2018 , an increase of 2.6 per cent from 2017 in real terms.

- Total military spending accounted for 2.1 per cent of global gross domestic product in 2018.

- The five biggest spenders in 2018 were the United States, China, Saudi Arabia, India and France, which together accounted for 60 per cent of global military spending. Russia was the sixth-largest spender in 2018.

- US military spending rose for the first time in seven years, to $\$ 649$ billion in 2018. China increased its military expenditure by 5.0 per cent and India by 3.1 per cent. Saudi Arabia decreased its military spending by 6.5 per cent, France by 1.4 per cent and Russia by 3.5 per cent.

- Military expenditure increased in Central America and the Caribbean, Central Europe, Central and South Asia, East Asia, North America, South America, and Western Europe.

- Military spending decreased in Eastern Europe, North Africa, Oceania, South East Asia, and sub-Saharan Africa. The total military expenditure of the countries in the Middle East for which data is available also decreased. 
Table 1. The 40 countries with the highest military expenditure in 2018

Spending figures and GDP are in US\$, at current prices and exchange rates. Changes are in real terms, based on constant (2017) US\$. Percentages below 10 are rounded to 1 decimal place; those over 10 are rounded to whole numbers. Figures and percentage shares may not add up to stated totals or subtotals due to the conventions of rounding.

\begin{tabular}{|c|c|c|c|c|c|c|c|}
\hline \multicolumn{2}{|l|}{ Rank } & \multirow[b]{2}{*}{ Country } & \multirow{2}{*}{$\begin{array}{l}\text { Spending (\$ b.), } \\
2018\end{array}$} & \multirow{2}{*}{$\begin{array}{l}\text { Change (\%), } \\
2009-18\end{array}$} & \multicolumn{2}{|c|}{ Spending as a share of GDP (\%) } & \multirow{2}{*}{$\begin{array}{l}\text { World share (\%), } \\
2018\end{array}$} \\
\hline 2018 & $2017^{a}$ & & & & 2018 & 2009 & \\
\hline 1 & 1 & United States & 649 & -17 & 3.2 & 4.6 & 36 \\
\hline 2 & 2 & China & {$[250]$} & 83 & [1.9] & {$[2.1]$} & {$[14]$} \\
\hline 3 & 3 & Saudi Arabia & {$[67.6]$} & 28 & {$[8.8]$} & 9.6 & [3.7] \\
\hline 4 & 5 & India & 66.5 & 29 & 2.4 & 2.9 & 3.7 \\
\hline 5 & 6 & France & 63.8 & 1.6 & 2.3 & 2.5 & 3.5 \\
\hline \multicolumn{3}{|c|}{ Subtotal top 5} & 1097 & .. & .. & .. & 60 \\
\hline 6 & 4 & Russia & 61.4 & 27 & 3.9 & 3.9 & 3.4 \\
\hline 7 & 7 & United Kingdom & 50.0 & -17 & 1.8 & 2.4 & 2.7 \\
\hline 8 & 9 & Germany & 49.5 & 9.0 & 1.2 & 1.4 & 2.7 \\
\hline 9 & 8 & Japan & 46.6 & 2.3 & 0.9 & 1.0 & 2.6 \\
\hline 10 & 10 & South Korea & 43.1 & 28 & 2.6 & 2.7 & 2.4 \\
\hline \multicolumn{3}{|c|}{ Subtotal top 10} & 1347 & .. & .. & .. & 74 \\
\hline 11 & 13 & Italy & 27.8 & -14 & 1.3 & 1.6 & 1.5 \\
\hline 12 & 11 & Brazil & 27.8 & 17 & 1.5 & 1.5 & 1.5 \\
\hline 13 & 12 & Australia & 26.7 & 21 & 1.9 & 1.9 & 1.5 \\
\hline 14 & 14 & Canada & 21.6 & 12 & 1.3 & 1.4 & 1.2 \\
\hline 15 & 15 & Turkey & 19.0 & 65 & 2.5 & 2.5 & 1.0 \\
\hline \multicolumn{3}{|c|}{ Subtotal top 15} & 1470 & .. & .. & .. & 81 \\
\hline 16 & 16 & Spain & 18.2 & -5.2 & 1.3 & 1.3 & 1.0 \\
\hline 17 & 17 & Israel & 15.9 & -5.8 & 4.3 & 6.8 & 0.9 \\
\hline 18 & 18 & Iran & 13.2 & -10 & 2.7 & 3.2 & 0.7 \\
\hline 19 & 24 & Poland & 11.6 & 48 & 2.0 & 1.8 & 0.6 \\
\hline 20 & 19 & Pakistan & 11.4 & 73 & 4.0 & 3.3 & 0.6 \\
\hline 21 & 25 & Netherlands & 11.2 & -4.4 & 1.2 & 1.4 & 0.6 \\
\hline 22 & 21 & Singapore & 10.8 & 13 & 3.1 & 3.9 & 0.6 \\
\hline 23 & 20 & Taiwan & 10.7 & -2.9 & 1.8 & 2.3 & 0.6 \\
\hline 24 & 23 & Colombia & 10.6 & 15 & 3.2 & 3.9 & 0.6 \\
\hline 25 & 22 & Algeria & 9.6 & 85 & 5.3 & 3.8 & 0.5 \\
\hline 26 & 26 & Indonesia & 7.4 & 99 & 0.7 & 0.6 & 0.4 \\
\hline 27 & 29 & Kuwait & 7.3 & 39 & 5.1 & 4.0 & 0.4 \\
\hline 28 & 30 & Norway & 7.1 & 23 & 1.6 & 1.6 & 0.4 \\
\hline 29 & 31 & Thailand & 6.8 & 16 & 1.3 & 1.8 & 0.4 \\
\hline 30 & 28 & Oman & {$[6.7]$} & 69 & {$[8.2]$} & {$[7.0]$} & {$[0.4]$} \\
\hline 31 & 32 & Mexico & 6.6 & 36 & 0.5 & 0.5 & 0.4 \\
\hline 32 & 27 & Iraq & 6.3 & 58 & 2.7 & 2.9 & 0.3 \\
\hline 33 & 33 & Sweden & 5.8 & 18 & 1.0 & 1.2 & 0.3 \\
\hline 34 & 35 & Chile & 5.6 & 25 & 1.9 & 2.3 & 0.3 \\
\hline 35 & 37 & Viet Nam & 5.5 & 76 & 2.3 & 2.3 & 0.3 \\
\hline 36 & 36 & Greece & 5.2 & -46 & 2.4 & 3.2 & 0.3 \\
\hline 37 & 39 & Belgium & 5.0 & -12 & 0.9 & 1.2 & 0.3 \\
\hline 38 & 38 & Switzerland & 4.8 & 6.3 & 0.7 & 0.7 & 0.3 \\
\hline 39 & 43 & Ukraine & 4.8 & 69 & 3.8 & {$[2.8]$} & 0.3 \\
\hline 40 & 46 & Romania & 4.6 & 112 & 1.9 & 1.3 & 0.3 \\
\hline \multicolumn{3}{|c|}{ Subtotal top 40} & 1683 & . & . & . & 93 \\
\hline \multicolumn{3}{|c|}{ World } & 1822 & 5.4 & 2.1 & 2.6 & 100 \\
\hline
\end{tabular}

.. = data not available or not applicable; [] = SIPRI estimate; GDP = gross domestic product.

${ }^{a}$ Rankings for 2017 are based on updated military expenditure figures in the current edition of the SIPRI Military Expenditure Database. They may therefore differ from the rankings for 2017 given in SIPRI Yearbook 2018 and in other SIPRI publications in 2018.

${ }^{b}$ The figures for military expenditure as a share of GDP are based on estimates of 2018 GDP from the International Monetary Fund World Economic Outlook and International Financial Statistics databases.

Sources: SIPRI Military Expenditure Database, Apr. 2019; International Monetary Fund, World Economic Outlook Database, Oct. 2018; and International Monetary Fund, International Financial Statistics Database, Sep. 2018. 


\section{THE TOP 15 MILITARY SPENDERS IN 2018}

The top 15 military spenders in the world in 2018 were the same as those in 2017 but there were some significant changes in the rankings (see table 1). ${ }^{1}$ Most notably, Russia ranked outside the top five for the first time since 2006. The five biggest spenders in 2018 were the United States, China, Saudi Arabia, India and France, which together accounted for 60 per cent of global military spending. The top 15 countries spent $\$ 1470$ billion in 2018 and accounted for 81 per cent of global military expenditure.

Between 2009 and 2018, all but three of the current top 15 countries increased their military expenditure, the exceptions being the United States ( -17 per cent), the United Kingdom ( -17 per cent) and Italy (-14 per cent). There were particularly large increases in spending over the decade by China (83 per cent) and Turkey (65 per cent). There were more moderate increases (i.e. 10-40 per cent) in the spending of Australia, Brazil, Canada, India, Russia, Saudi Arabia and South Korea, and minor increases (i.e. less than 10 per cent) by France, Germany and Japan.

At $\$ 649$ billion, US military expenditure increased-for the first time in seven years-by 4.6 per cent in 2018 . The USA remained by far the largest spender in the world, accounting for 36 per cent of global military spending in 2018 (see figure 2). The USA spent almost as much on its military in 2018 as the next eight highest spenders combined. However, its military expenditure in 2018 was still 19 per cent lower than its peak in 2010. The US Government's budget-adoption process has been particularly difficult during the 2010s, in the context of efforts to address the US deficit and balance the country's budget. This has led to severe and antagonistic divisions in the Congress and between the Congress and the administration on the level of resources dedicated to the US military.

China, the world's second-largest military spender, allocated $\$ 250$ billion to the military in 2018, which accounted for 14 per cent of global spending. In 2018 its military expenditure rose for the 24th consecutive year, and its spending in 2018 was almost 10 times higher than in 1994. The annual rate of growth of China's military spending has slowed steadily since it reached a post-2009 high of 9.3 per cent in 2013. The growth of 5.0 per cent in 2018 was the lowest annual increase since 1995. China has followed a policy of linking growth in military spending with economic growth. With its economic growth slowing in 2018 to the lowest level in 28 years, slower rates of growth in the coming years can be expected if China continues to follow this policy.

Despite a 6.5 per cent decrease in its military spending between 2017 and 2018, Saudi Arabia remained the third-largest spender in the world, with an estimated total of $\$ 67.6$ billion. At $\$ 66.5$ billion, India was the fourth-largest spender in 2018. Its military expenditure rose by 29 per cent over the decade 2009-18. Despite a minor decrease (1.4 per cent) in its military spending between 2017 and 2018, France moved up one place in the rankings to fifth, due to Russia's fall from fourth to sixth position.

Seven of the 15 highest spenders are members of the North Atlantic Treaty Organization (NATO): Canada, France, Germany, Italy, Turkey, the UK and

\footnotetext{
1 The United Arab Emirates would probably rank as one of the 15 largest spenders, most likely in the range 11-15, but a lack of data since 2014 means that no reasonable estimate of its military spending can be made and thus it has been omitted from the ranking.
} 
the USA. Together, these seven accounted for 48 per cent ( $\$ 880$ billion) of global military expenditure in 2018. Total spending by all 29 NATO members was $\$ 963$ billion in 2018.

\section{REGIONAL TRENDS}

Total military spending increased in the Americas (by 4.4 per cent), Asia and Oceania (by 3.3 per cent) and Europe (by 1.4 per cent) between 2017 and 2018. The rise in military spending in 2018 in the Americas was the first since 2010, while the rise in Europe, which experienced fluctuating levels of spending between 2009 and 2018, was the sixth annual increase in the past decade. In Asia and Oceania, spending has risen every year since reliable regional estimates became available in 1988. In contrast, military expenditure in Africa fell for the fourth consecutive year in 2018. Overall military spending by states in the Middle East for which data is available also fell in 2018, by 1.9 per cent.

\section{Africa}

Military expenditure in Africa fell by 8.4 per cent in 2018 to an estimated $\$ 40.6$ billion or 2.2 per cent of global military spending (see table 2 ). This was the largest relative annual decrease since the post-cold war peak reached in 2014. Despite four consecutive years of decreases, military expenditure in Africa was still 9.2 per cent higher in 2018 than in 2009.

Military spending in North Africa totalled $\$ 22.2$ billion in 2018. This was a decrease of 5.5 per cent compared with 2017 and the second consecutive year of decline (see figure 3). Nonetheless, spending in 2018 was 74 per cent higher than in 2009. In sub-Saharan Africa, military spending was $\$ 18.4$ billion in 2018, down by 11 per cent from 2017 and 21 per cent lower than in 2009. The large decrease meant that, for the first time, North Africa (with only four countries) spent more than sub-Saharan Africa (with 45 countries). ${ }^{2}$

With a total of $\$ 9.6$ billion in 2018, Algeria had by far the highest military spending in Africa. While in nominal terms Algeria's military spending has remained the same since 2016, inflation meant that military expenditure fell in real terms by 6.1 per cent between 2017 and 2018 .

The decreases in spending by Angola and Sudan (-18 per cent and -49 per cent, respectively) largely accounted for the decline in military spending in sub-Saharan Africa in 2018 (see table 3). Angola's military expenditure fell for the fourth consecutive year in 2018 to reach $\$ 2.0$ billion. Lower oil prices since mid-2014 have placed the Angolan economy under severe stress, leading to cuts in government expenditure, including military spending. Sudan has faced a combination of economic crisis, continued violent conflict in the Darfur region and a surge in anti-government protests. This has contributed to the volatile development of Sudan's military spending over the past five years, with decreases in spending in three years (2014, 2015 and 2018) and increases in two years (2016 and 2017).

\footnotetext{
${ }^{2}$ The total for sub-Saharan Africa excludes the Comoros and Sao Tome and Principe, which are assumed to have low expenditure, and Eritrea and Somalia, for which data is unavailable.
} 
Another notable decrease in military spending in sub-Saharan Africa in 2018 occurred in South Sudan ( -50 per cent). The fall in South Sudan's military spending, the seventh over the past 10 years, arose in the context of the civil war in the country, which pushed the economy into further disarray. At $\$ 59.4$ million, South Sudanese military spending in 2018 was only 4.2 per cent of the peak reached in 2011. This is a low figure and does not include the unknown level of funding to the military that is reportedly channelled from South Sudan's state-owned oil company.

In contrast to the cuts described above, Nigeria, sub-Saharan Africa's second-largest spender behind South Africa, increased its military spending for the first time in six years, by 18 per cent to $\$ 2.0$ billion in 2018 .

\section{The Americas}

At $\$ 735$ billion, military expenditure in the Americas in 2018 accounted for 40 per cent of global military spending. Three countries from the region are included in the top 15 global spenders in 2018: USA (rank 1), Brazil (rank 12) and Canada (rank 14). Military expenditure in the region grew by 4.4 per cent between 2017 and 2018. However, spending in 2018 remained 14 per cent lower than in 2009. Spending by the two countries in North America (Canada and the USA) accounted for 91 per cent of the total for the Americas. North America's total of $\$ 670$ billion represented an increase of 4.4 per cent compared with 2017 but was still 16 per cent lower than in 2009.

Between 2017 and 2018, military spending in Central America and the Caribbean increased by 8.8 per cent to $\$ 8.6$ billion. Subregional spending in 2018 was 39 per cent higher than in 2009. South American military spending grew by 3.1 per cent (to $\$ 55.6$ billion) in 2018 , the second annual increase since 2014. Military expenditure in South America was 16 per cent higher in 2018 than in 2009.

The main contributors to total South American military spending were Brazil (50 per cent), Colombia (19 per cent), Chile (10 per cent) and Argentina (7.5 per cent). Together, they accounted for about 87 per cent of the subregion's spending in 2018.

Brazil's military expenditure grew by 5.1 per cent between 2017 and 2018 (to $\$ 27.8$ billion) and by 17 per cent between 2009 and 2018. Spending increased despite Brazil's ongoing economic slowdown and public expenditure constraints.

Venezuela was the second-largest spender in South America as recently as 2013. Since then, however, its military spending has fallen substantially due to a severe economic crisis: spending fell by 71 per cent between 2013

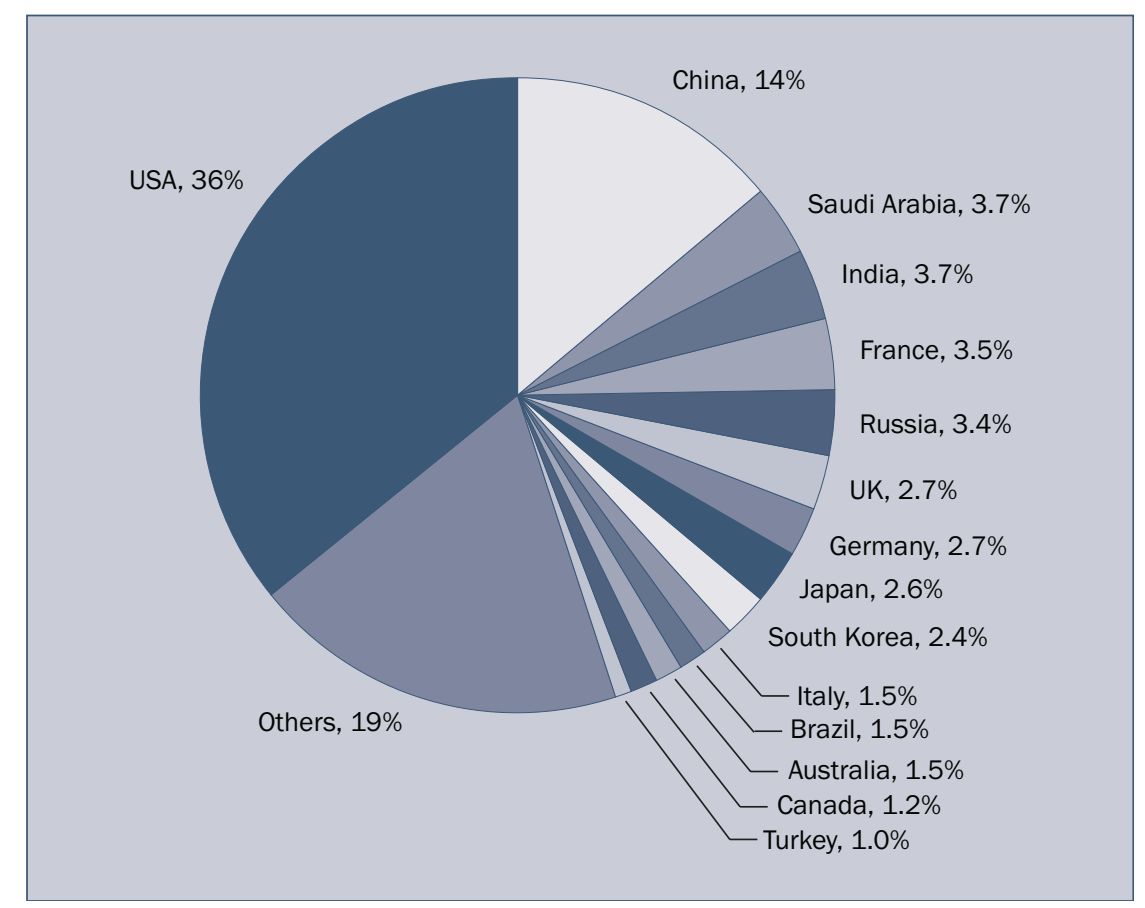

Figure 2. The share of world military expenditure of the 15 countries with the highest spending in 2018

Source: SIPRI Military Expenditure Database, Apr. 2019. 
Table 2. Military expenditure, by region and subregion, 2018

Spending figures are in US\$, at current prices and exchange rates. Changes are in real terms, based on constant (2017) US\$. Percentages below 10 are rounded to 1 decimal place; those over 10 are rounded to whole numbers. Figures and percentage shares may not add up to stated totals or subtotals due to the conventions of rounding.

\begin{tabular}{|c|c|c|c|c|}
\hline \multirow[b]{2}{*}{ Region and subregion } & \multirow{2}{*}{$\begin{array}{l}\text { Spending (\$ b.), } \\
2018\end{array}$} & \multicolumn{2}{|c|}{ Change (\%) } & \multirow{2}{*}{$\begin{array}{l}\text { World share (\%), } \\
2018\end{array}$} \\
\hline & & 2017-18 & 2009-18 & \\
\hline World & 1822 & 2.6 & 5.4 & 100 \\
\hline Africa ${ }^{a}$ & (40.6) & -8.4 & 9.2 & 2.2 \\
\hline North Africa & $(22.2)$ & -5.5 & 74 & 1.2 \\
\hline Sub-Saharan Africa ${ }^{a}$ & 18.4 & -11 & -21 & 1.0 \\
\hline Americas $^{b}$ & 735 & 4.4 & -14 & 40 \\
\hline Central America and the Caribbean ${ }^{b}$ & 8.6 & 8.8 & 39 & 0.5 \\
\hline North America & 670 & 4.4 & -16 & 37 \\
\hline South America & 55.6 & 3.1 & 16 & 3.1 \\
\hline Asia and Oceaniac & 507 & 3.3 & 46 & 28 \\
\hline Central and South Asia ${ }^{d}$ & 85.9 & 4.2 & 36 & 4.7 \\
\hline East Asia $^{e}$ & 350 & 4.1 & 54 & 19 \\
\hline Oceania & 29.1 & -2.9 & 20 & 1.6 \\
\hline South East Asia & 41.9 & -0.8 & 33 & 2.3 \\
\hline Europe & 364 & 1.4 & 3.1 & 20 \\
\hline Central Europe & 28.3 & 12 & 35 & 1.6 \\
\hline Eastern Europe & 69.5 & -1.7 & 29 & 3.8 \\
\hline Western Europe & 266 & 1.4 & -4.9 & 15 \\
\hline Middle East ${ }^{f}$ & .. & .. &. & .. \\
\hline
\end{tabular}

.. = data not available or not applicable; ()$=$ uncertain estimate.

${ }^{a}$ Figures exclude Eritrea and Somalia.

${ }^{b}$ Figures exclude Cuba.

${ }^{c}$ Figures exclude North Korea, Turkmenistan and Uzbekistan.

${ }^{d}$ Figures exclude Turkmenistan and Uzbekistan.

${ }^{e}$ Figures exclude North Korea.

${ }^{f}$ No SIPRI estimate for the Middle East is available for 2015-18. A rough estimate for the Middle East (excluding Qatar and Syria) is included in the world total.

Source: SIPRI Military Expenditure Database, Apr. 2019.

and 2017. SIPRI has not estimated Venezuela's military expenditure in current or constant US dollars or as a share of GDP in 2018 due to a lack of reliable data. Only an estimate of the nominal military budget for 2018 in local currency is provided in the Military Expenditure Database.

Mexico's military spending accounted for 77 per cent of the total military expenditure in Central America and the Caribbean. Its military spending grew by 10 per cent (to $\$ 6.6$ billion) in 2018 -the first annual increase since 2015. For over a decade Mexico has militarized its law enforcement efforts to combat drug cartels by deploying the military alongside the national police and the gendarmerie.

\section{Asia and Oceania}

Military spending in Asia and Oceania was $\$ 507$ billion in 2018 and accounted for 28 per cent of global military spending. Five of the top 15 global spenders in 2018 are in this region: China (rank 2), India (rank 4), Japan (rank 9), South Korea (rank 10) and Australia (rank 13). It is the only region in which annual growth has been continuous since 1988, and the 46 per cent increase between 2009 and 2018 was by far the largest of any region. The increase was 
due primarily to the rise in Chinese spending, which in 2018 accounted for 49 per cent of total spending in the region, compared with 31 per cent in 2009.

Between 2017 and 2018, military spending increased in Central and South Asia (4.2 per cent) and in East Asia (4.1 per cent), while spending decreased in South East Asia ( -0.8 per cent) and Oceania ( -2.9 per cent). There were substantial increases in all four subregions between 2009 and 2018, ranging from 20 per cent in Oceania to 54 per cent in East Asia. Military expenditure fell between 2009 and 2018 in only 8 of the 27 countries in Asia and Oceania with data available for 2018.

India's military spending rose in 2018 for the fifth consecutive year, and was 3.1 per cent higher than in 2017. At $\$ 66.5$ billion, India's spending was 29 per cent higher than in 2009. Despite this rise, India's military burden in 2018 was at one of its lowest levels since the early 1960s: 2.4 per cent of GDP compared with 2.9 per cent in 2009. Increases in Indian military expenditure are largely motivated by tensions and rivalry with Pakistan and China.

Pakistan's military spending in 2018 was $\$ 11.4$ billion, making it the 20th-largest spender globally. Pakistan's military spending has increased every year since 2009. It rose by 73 per cent between 2009 and 2018 and by 11 per cent between 2017 and 2018. Pakistan's military burden in 2018 was 4.0 per cent of GDP-the highest level since 2004.

Military spending by Japan was $\$ 46.6$ billion in 2018 , almost unchanged from 2017 (down by 0.1 per cent). Japan's military spending as a share of GDP in 2018 was 0.9 per cent.

In South Korea the upward trend in military spending since 2000 continued. In 2018 its military expenditure reached $\$ 43.1$ billion, an increase of 5.1 per cent compared with 2017 and of 28 per cent compared with 2009.

Australian military spending was $\$ 26.7$ billion in 2018 . It grew by 21 per cent between 2009 and 2018 but fell by 3.1 per cent between 2017 and 2018. Australia's military expenditure, including major arms procurement, has risen over the past decade in response to a perceived increase in threats to its security.

Some of the smaller spenders in Asia and Oceania, such as Malaysia and Afghanistan, have made notable decreases over the past few years. Despite ongoing tensions with its neighbours over rights in the South China Sea and its strong economic growth in recent years, Malaysia's military spending fell in 2018 ( -8.2 per cent) for the third consecutive year. The decreases are part of an effort to reduce the country's budget deficit and debts.

By 2017 Afghanistan's military expenditure had dropped by 26 per cent compared with 2009 but in 2018 spending increased by 6.7 per cent to $\$ 198$ million. Afghanistan's military burden of 1.0 per cent of GDP in 2018

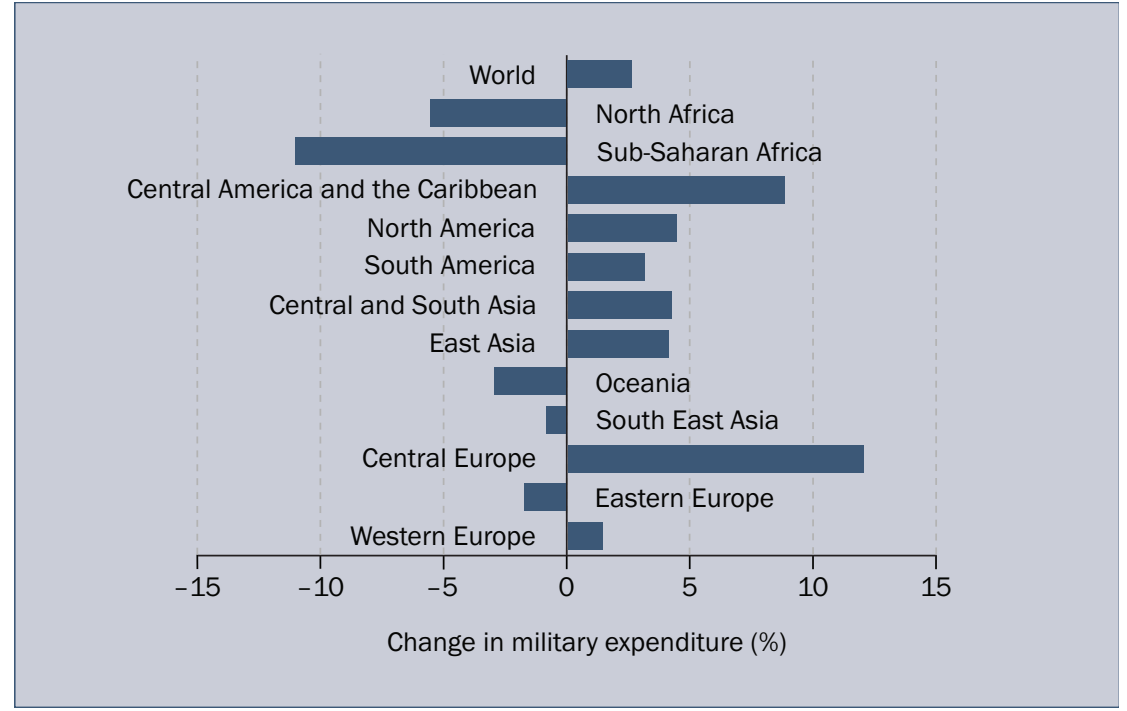

Figure 3. Changes in military expenditure, by subregion, 2017-18

Note: No estimate of change in military expenditure in the Middle East is given since data for 2015-18 is highly uncertain. However, an estimate for the Middle East is included in the estimated world total.

Source: SIPRI Military Expenditure Database, Apr. 2019. 
Table 3. The biggest relative increases and decreases in military expenditure, 2017-18

Spending figures are in US\$, at current prices and exchange rates. Changes are in real terms, based on constant (2017) US\$. Percentages below 10 are rounded to 1 decimal place; those over 10 are rounded to whole numbers. Countries with military expenditure in 2018 of less than $\$ 100 \mathrm{~m}$. (or $\$ 50 \mathrm{~m}$. in Africa) are excluded.

\begin{tabular}{|c|c|c|c|c|c|c|}
\hline Rank & Country & $\begin{array}{l}\text { Spending (\$ m.), } \\
2018\end{array}$ & $\begin{array}{l}\text { Increase (\%), } \\
2017-18\end{array}$ & Country & $\begin{array}{l}\text { Spending (\$ m.), } \\
2018\end{array}$ & $\begin{array}{l}\text { Decrease (\%), } \\
2017-18\end{array}$ \\
\hline 1 & Burkina Faso & 312 & 52 & South Sudan & 59.4 & -50 \\
\hline 2 & Jamaica & 208 & 40 & Sudan & 1048 & -49 \\
\hline 3 & Armenia & 609 & 33 & Benin & 90.2 & -28 \\
\hline 4 & Bosnia and Herzegovina & 221 & 26 & Congo, Republic of the & 292 & -27 \\
\hline 5 & Turkey & 18967 & 24 & Trinidad and Tobago & 169 & -18 \\
\hline 6 & Latvia & 680 & 24 & Angola & 1984 & -18 \\
\hline 7 & Bulgaria & 1096 & 23 & Iraq & 6318 & -16 \\
\hline 8 & Ukraine & 4750 & 21 & Bahrain & 1397 & -11 \\
\hline 9 & Zimbabwe & 420 & 19 & Gabon & 261 & -10 \\
\hline 10 & Lithuania & 1030 & 18 & DRC & 295 & -10 \\
\hline 11 & Czechia & 2710 & 18 & Iran & 13194 & -9.5 \\
\hline 12 & Nigeria & 2043 & 18 & Myanmar & 2030 & -8.9 \\
\hline 13 & Romania & 4609 & 18 & Lesotho & 51.1 & -8.8 \\
\hline 14 & Uganda & 408 & 17 & Sri Lanka & 1681 & -8.4 \\
\hline 15 & Kazakhstan & 1614 & 16 & Malaysia & 3470 & -8.2 \\
\hline
\end{tabular}

DRC $=$ Democratic Republic of the Congo.

Source: SIPRI Military Expenditure Database, Apr. 2019.

is perhaps surprisingly low considering the high intensity of the conflict between the Afghan Government and the Taliban insurgency. However, most of the financial cost of the war in Afghanistan has been shouldered by the USA.

\section{Europe}

Total military expenditure in Europe increased by 1.4 per cent to $\$ 364$ billion in 2018. Spending increased in Central Europe and Western Europe and decreased in Eastern Europe. Europe accounted for 20 per cent of global military expenditure, making it the third-largest spending region, behind the Americas and Asia and Oceania. Five of the world's 15 largest military spenders are in Europe: France (rank 5), Russia (rank 6), the UK (rank 7), Germany (rank 8) and Italy (rank 11).

Military spending in Western Europe was $\$ 266$ billion in 2018, representing nearly three-quarters of European spending. It was up by 1.4 per cent from 2017 but down by 4.9 per cent from 2009. Military spending in Eastern Europe was $\$ 69.5$ billion in 2018, a 1.7 per cent decrease compared with 2017 but 29 per cent higher than in 2009. At $\$ 28.3$ billion in 2018, military expenditure in Central Europe accounted for 7.8 per cent of the European total. In 2018 spending in the subregion grew by 12 per cent compared with 2017 and by 35 per cent compared with 2009 . The increases in military spending in the subregion are largely due to growing perceptions of a threat from Russia.

France's military spending fell by 1.4 per cent in 2018 to $\$ 63.8$ billion, following four consecutive years of increases starting in 2014. The increases in 2014-17 were driven by costs associated with external military operations and a large domestic military operation to guard key public locations after the terrorist attacks in Paris in 2015. 
Military spending by the UK increased by 1.0 per cent between 2017 and 2018 , to reach $\$ 50.0$ billion. However, over the decade 2009-18 British military expenditure decreased by 17 per cent. Following sharp falls in the first years of that decade, British military spending has been relatively stable since 2015. However, it is unclear whether the current level of spending will be sufficient to fully sustain the UK's long-term arms modernization programme.

Military expenditure by Germany, the third-largest military spender in Western Europe, was $\$ 49.5$ billion in 2018, representing 1.2 per cent of its GDP. Its spending was 1.8 per cent higher than in 2017 and 9.0 per cent higher than in 2009. Germany aims to play a greater role in global security and plans to increase its military expenditure to 1.5 per cent of GDP by 2025 .

Russian military spending was $\$ 61.4$ billion in 2018 , which accounted for 88 per cent of East European military spending. Russia's major military modernization programme, which started in 2010, led to significant annual increases in military spending (between 4.9 per cent and 16 per cent) through 2015. Starting in 2016 Russia's military budget has trended downwards. However, due to a one-off government debt repayment of almost $\$ 11.8$ billion to Russian arms producers in 2016, spending rose by 7.2 per cent; without this payment, Russian military spending would have fallen by 11 per cent. The payment also explains a large part of the sharp 19 per cent drop in 2017: excluding the repayment, spending would have decreased by 2.8 per cent. Russia's spending fell again in 2018 (by 3.5 per cent), but it is still 27 per cent higher than in 2009.

Ukraine's military spending in 2018 was $\$ 4.8$ billion (see table 3). This represented an increase of 21 per cent compared with 2017 and of 53 per cent compared with 2013, the year before major armed conflict broke out in Ukraine.

Poland, which is by far the largest spender in Central Europe, accounted for 41 per cent of the subregional total in 2018. At $\$ 11.6$ billion in 2018, Poland's military spending was 8.9 per cent higher than in 2017 and 48 per cent higher than in 2009. Lithuania had the highest relative increase in military spending of all European countries between 2009 and 2018: its spending rose by 156 per cent over the decade.

\section{The Middle East}

SIPRI has not estimated total military expenditure in the Middle East since 2014 because of a lack of data for Qatar, Syria, the United Arab Emirates (UAE) and Yemen. The combined total military expenditure for the 11 countries for which data is available in 2018 was $\$ 145$ billion. ${ }^{3}$ The spending totals for these countries increased every year between 2009 and 2015 followed by a significant decrease in 2016. Spending increased again in 2017 but fell by 1.9 per cent in 2018.

Two of the top 15 global spenders in 2018 are in the Middle East: Saudi Arabia (rank 3) and Turkey (rank 15). Saudi Arabia is by far the largest military spender in the region, with an estimated total of $\$ 67.6$ billion in 2018. After an increase of 72 per cent between 2009 and 2015, when Saudi Arabia's military expenditure reached its peak, spending dropped by 28 per cent in

\footnotetext{
${ }^{3}$ Countries included in the estimate are Bahrain, Egypt, Iran, Iraq, Israel, Jordan, Kuwait, Lebanon, Oman, Turkey and Saudi Arabia.
} 


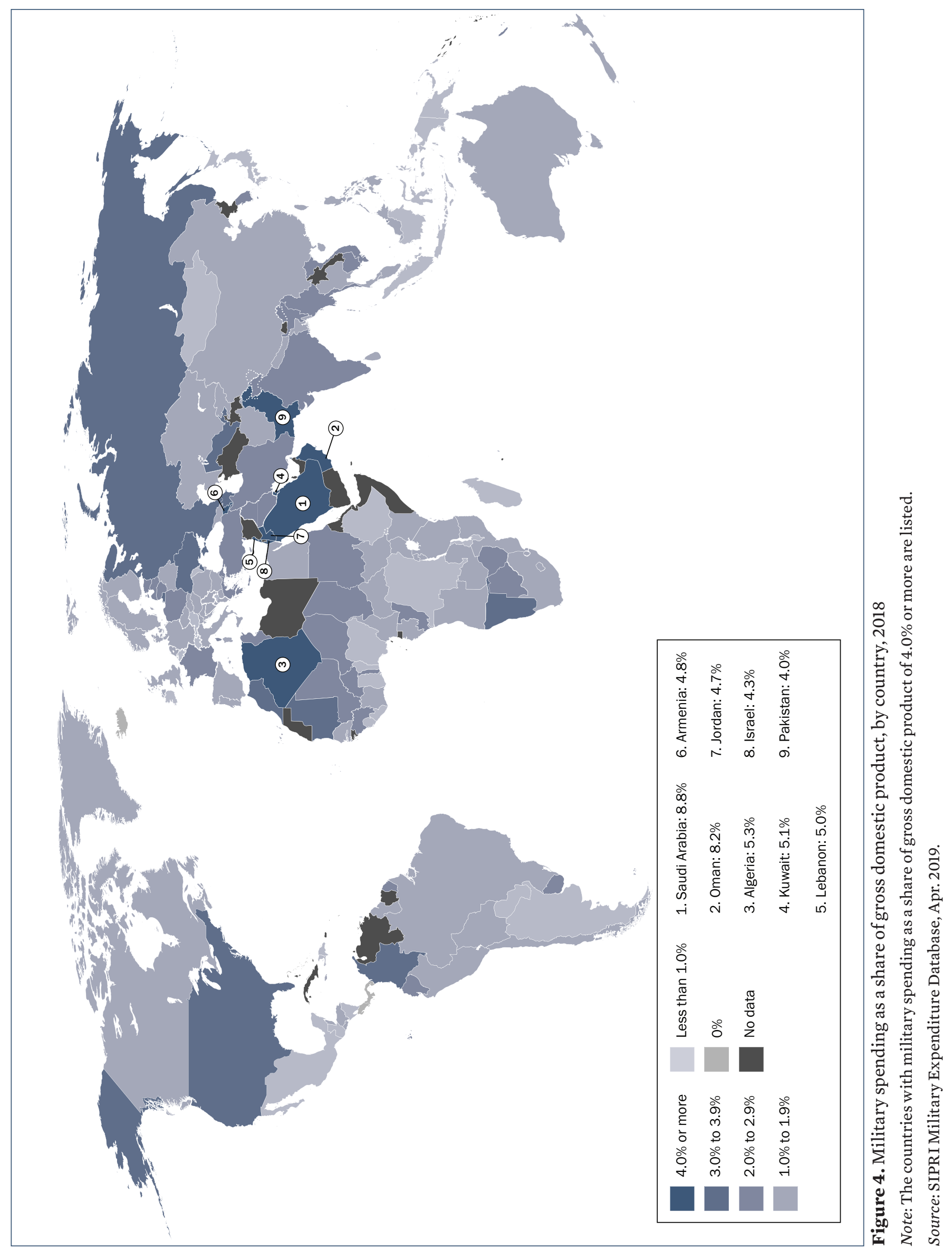


2016 as falling oil prices caused a decline in government revenue. Military spending increased by 11 per cent in 2017 but decreased by 6.5 per cent in 2018. The fall in 2018 occurred despite Saudi Arabia's high levels of arms imports and the continuation of its military intervention in Yemen.

Between 2009 and 2018, Turkish military expenditure increased by 65 per cent to reach $\$ 19.0$ billion. In 2018 alone spending grew by 24 per cent, the highest increase in military expenditure among the top 15 military spenders. Funding for arms procurement increased rapidly in 2018 and Turkey also expanded its military operation against Kurdish armed groups in Syria.

The most recent available estimate for military spending by the UAE is $\$ 22.8$ billion (current US dollars) in 2014. Considering its ongoing military operations abroad and large arms procurement projects, it can be assumed that its spending remains at or above the 2014 level.

Iran's military expenditure was $\$ 13.2$ billion in 2018. It decreased by 9.5 per cent between 2017 and 2018 as the Iranian economy went into recession and inflation increased from 10 per cent in 2017 to 30 per cent in 2018.

Israel's military spending was $\$ 15.9$ billion in 2018 , a marginal increase of 0.7 per cent compared with 2017. After a peak in 2015-related to military operations in 2014 in the Gaza Strip-Israeli military expenditure decreased by 13 per cent in 2016 and by 1.0 per cent in 2017 .

At $\$ 3.1$ billion, Egyptian military expenditure in 2018 was 7.3 per cent lower than in 2017 and 20 per cent lower than in 2009. However, it remains unclear how Egyptian military spending can be declining while the country is involved in major military operations in the Sinai peninsula and is implementing major arms procurement programmes.

\section{THE MILITARY BURDEN}

A state's military expenditure as a share of GDP-also known as the military burden-is the simplest measure of the relative economic burden the military places on that state. While military burden varies widely between regions and between countries, the general trend is that military spending as a share of GDP has decreased in all regions since 1999. The world military burden of 2.1 per cent in 2018 was 0.5 percentage points lower than in 2009.

On average, states in the Americas had the lowest military burden in 2018, at 1.4 per cent of GDP; this rises to an average of 1.6 per cent in Europe, 1.7 per cent in both Africa and Asia and Oceania, and 4.4 per cent in the Middle Eastern countries for which data is available.

Of the countries for which SIPRI has military burden data, only 20 allocated 3.0 per cent or more of their GDP to the military in 2018, and around two-thirds had a burden of less than 2.0 per cent of GDP (see figure 4). Thirty-three countries allocated less than 1.0 per cent of their GDP to the military in 2018. Of the countries that allocated funding to the military, Haiti had the lowest military burden (0.01 per cent of GDP).

Six of the 10 countries with the highest military burden in the world in 2018 are in the Middle East: Saudi Arabia (8.8 per cent of GDP), Oman (8.2 per cent), Kuwait (5.1 per cent), Lebanon (5.0 per cent), Jordan (4.7 per cent) and Israel (4.3 per cent). The other four are Algeria ( 5.3 per cent), Armenia (4.8 per cent), Pakistan (4.0 per cent) and Russia (3.9 per cent). 
SIPRI is an independent international institute dedicated to research into conflict, armaments, arms control and disarmament. Established in 1966, SIPRI provides data, analysis and recommendations, based on open sources, to policymakers, researchers, media and the interested public.

\section{GOVERNING BOARD}

Ambassador Jan Eliasson, Chair (Sweden)

Dr Dewi Fortuna Anwar (Indonesia)

Dr Vladimir Baranovsky (Russia)

Espen Barth Eide (Norway) Jean-Marie Guéhenno (France)

Dr Radha Kumar (India)

Dr Patricia Lewis (Ireland/

United Kingdom)

Dr Jessica Tuchman Mathews

(United States)

\section{DIRECTOR}

Dan Smith (United Kingdom)

\section{The SIPRI Military Expenditure Database}

The SIPRI Military Expenditure Database provides military expenditure data by country for the years 1949-2018 in local current prices, constant US dollars, current US dollars, as a share of gross domestic product (GDP), per capita and as a share of total government expenditure. The SIPRI Military Expenditure Database was updated on 29 April 2019. This version replaces all previous versions of the database. The database and further details on the definitions (including regional coverage), sources and methods used are available on the Military Expenditure Database web page of the SIPRI website.

All figures for spending in 2018 are given in 2018 current US dollars. Figures for relative increases or decreases in military spending-often described as changes in 'real terms' or adjusted for inflation-are expressed in constant (2017) US dollars. The large differences in 2018 military expenditure when expressed in current 2018 US dollars compared with constant 2017 US dollars are caused by a combination of the overall depreciation of the US dollar against many other currencies and differing price levels between 2017 and 2018 in all countries.

\section{Sources}

SIPRI data reflects the official data reported by national governments. Such data is found in official publications such as budget documents. Of the 168 countries for which SIPRI attempted to estimate military expenditure in 2018 , relevant data was found for 155

\section{Definitions}

Where possible, SIPRI military expenditure data includes all current and capital expenditure on (a) the armed forces, including peacekeeping forces; (b) defence ministries and other government agencies engaged in defence projects; (c) paramilitary forces, when judged to be trained and equipped for military operations; and (d) military space activities. This data should include expenditure on personnelwhich encompasses salaries of military and civil personnel and pensions and social services of military personnel-as well as expenditure related to operations and maintenance, procurement, military research and development, and military aid (in the military expenditure of the donor country).

Civil defence and current expenditure on previous military activities, such as veterans' benefits, demobilization, conversion, weapon destruction and military involvement in non-military activities (e.g. policing) are excluded when disaggregated data is available.

\section{sipri}

STOCKHOLM INTERNATIONAL PEACE RESEARCH INSTITUTE

Signalistgatan 9

SE-169 72 Solna, Sweden

Telephone: +4686559700

Email:sipri@sipri.org

Internet: www.sipri.org

\section{ABOUT THE AUTHORS}

Aude Fleurant (Canada/France) is the director of the SIPRI Arms and Military Expenditure Programme. Pieter D. Wezeman (Netherlands/Sweden) and Siemon T. Wezeman (Netherlands) are senior researchers, Nan Tian (China/South Africa) is a researcher and Alexandra Kuimova (Russia) is a research assistant in the programme. 